\title{
Penerapan Teknik Pembelajaran Kooperatif NHT dalam Meningkatkan Pemahaman tentang Bumi Bagian dari Alam Semesta
}

\author{
Aniq Royani
}

SDN Kepanjenkidul 2

Email: aniqroyani@yahoo.com

\section{Tersedia Online di \\ http://www.jurnal.unublitar.ac.id/ index.php/briliant}

\begin{tabular}{l}
\hline Sejarah Artikel \\
\hline Diterima pada 30 Mei 2017 \\
Disetuji pada 10 Juli 2017 \\
Dipublikasikan pada: 2 Agustus \\
2017 Hal 294-311 \\
\hline
\end{tabular}

Kata Kunci:

Teknik pembelajaran kooperatif nht, pemahaman

\begin{abstract}
Abstrak: Penelitian ini bertujuan mendeskripsikan penerapan teknik pembelajaran koperatif NHT dan mendeskripsikan peningkatan pemahaman tentang bumi bagian dari alam semesta setelah diterapkannya teknik pembelajaran kooperatif NHT pada siswa kelas III SDN Kepanjenkidul 2. Jenis penelitian ini adalah Penelitian Tindakan Kelas dengan bentuk penelitian tindakan guru sebagai peneliti. Penerapan Teknik Pembelajaran Kooperatif NHT pada siswa kelas III SDN Kepanjenkidul 2 tentang Bumi Bagian dari Alam Semesta teruji efektif dengan kenaikan persentase hasil yang selalu konsisten dari pertemuan ke-1, pertemuan ke-2 siklus I dan pertemuan ke-1, pertemuan ke-2 siklus II.
\end{abstract}

Pada tahun 2013 Kementrian Pendidikan dan Kebudayaan telah mengembangkan kurikulum baru sebagai kelanjutan dari Pengembangan Kurikulum Berbasis Kompetensi yang telah dirintis pada tahun 2004 dan KTSP 2006 Kurikulum Tingkat Satuan Pendidikan yang kemudian dikenal dengan Kurikulum 2013. mencakup kompetensi sikap, pengetahuan dan keterampilan secara terpadu.

Dengan adanya kenyataan tersebut, Kurikulum 2013 berorientasi meningkatkan dan menyeimbangkan antara kompetensi sikap (attitude), keterampilan (skill), dan pengetahuan (knowledge).

Keberhasilan implementasi kurikulum di SD dalam pembelajaran sangat ditentukan oleh para pemangku kepentingan, utamanya guru. Guru harus memiliki pemahaman, kesadaran, kemampuan, kreativitas, kesabaran dan keuletan agar dapat meramu wawasan pembelajaran yang lebih menarik dan disukai oleh peserta didik.

Masalah yang umum terjadi dalam pembelajaran saat ini yakni masih rendahnya daya serap peserta didik. Hal ini tampak dari rerata hasil belajar peserta didik yang senantiasa masih memprihatinkan. Keadaan tersebut menunjukkan bahwa proses pembelajaran hingga dewasa ini masih didominasi guru dan tidak memberikan akses bagi anak didik untuk berkembang secara mandiri melalui penemuan dalam proses berpikirnya. Suasana kelas cenderung teacher-centered, sehingga siswa menjadi pasif. Walaupun demikian guru masih sering menerapkan model tersebut, karena lebih mudah, tidak memerlukan alat dan bahan praktik, cukup menjelaskan konsep yang ada pada buku ajar atau referensi lain. Siswa tidak mendapatkan strategi belajar yang dapat memahami bagaimana belajar, berpikir dan memotivasi diri sendiri (self motivation), yang merupakan kunci

294 BRILIANT: Jurnal Riset dan Konseptual Volume 2 Nomor 3, Agustus 2017 
keberhasilan dalam suatu pembelajaran. Masalah ini banyak dijumpai dalam kegiatan proses pembelajaran di kelas, sebagaimana terjadi di kelas III SDN Kepanjenkidul 2 Kota Blitar. Guru masih sering menggunakan metode ekspositori. Keadaan tersebut berdampak pada siswa antara lain : siswa banyak yang pasif, tidak mau bertanya, beberapa siswa asyik main sendiri, beberapa siswa tampak tidak tertarik dengan pembelajaran tema 8 Sub Tema Bumi Bagian dari Alam Semesta, siswa kurang memahami Bumi bagian alam semesta terbukti dengan nilai siswa yang belum mencapai KKM mencapai $52 \%$.

Melihat kondisi ini, guru memperbaiki proses pembelajaran dengan teknik pembelajaran yang dapat meningkatkan pemahaman siswa. Dalam hal ini guru memilih teknik NHT. Teknik Numbered Head Together (NHT) sering lebih dikenal dengan metode NHT. NHT atau penomoran berpikir bersama merupakan jenis teknik pembelajaran kooperatif yang dirancang untuk mempengaruhi pola interaksi siswa dan sebagai alternatif terhadap struktur kelas tradisional. Numbered Head Together pertama kali dikembangkan oleh Spenser Kagen pada tahun 1993 untuk melibatkan lebih banyak siswa dalam menelaah materi yang tercakup dalam suatu pelajaran dan mengecek pemahaman mereka terhadap isi pelajaran tersebut.

Penelitian tindakan kelas ini bertujuan untuk : mendeskripsikan penerapan teknik pembelajaran koperatif NHT dalam meningkatkan pemahaman tentang bumi bagian dari alam semesta pada siswa kelas III SDN Kepanjenkidul 2 dan mendeskripsikan peningkatan pemahaman siswa kelas III SDN Kepanjenkidul 2 setelah diterapkannya teknik pembelajaran kooperatif NHT.

Dalam teori belajar kognitif dijelaskan bahwa "memperoleh pamahaman berarti menangkap makna atau arti dari suatu obyek atau situasi yang dihadapi (Sumiati, 2009). Sementara itu Teori belajar Gestalt mengisyaratkan bahwa pemahaman (insight) akan timbul jika individu telah dapat melihat hubungan antara unsur-unsur dalam situasi yang bersifat problematik (Sumiati, 2009). Pemahaman merupakan jenjang kemampuan berpikir yang setingkat lebih tinggi dari ingatan dan hafalan.

Huda (2013) menerangkan bahwa hingga saat ini ada 19 metode, 14 teknik, dan 15 struktur pembelajaran kooperatif yang telah dikembangkan oleh berbagai pakar di belahan dunia. Antara metode teknik, dan struktur tentu terdapat perbedaan-perbedaan mendasar. Jika mengikuti pengertian standarnya masingmasing, metode bisa dipahami sebagai cara kerja yang teratur dan bersistem untuk dapat melaksanakan suatu kegiatan dengan mudah dan sistematis, teknik merupakan jabaran metode sesuai dengan alat dan sifat alat yang dipakai, struktur: merupakan unsur-unsur yang diperlukan untuk membangun sesuatu berdasarkan pola tertentu, prosedur merupakan urutan penerapan/penggunaan teknik.

Dalam pembelajaran kooperatif, sulit dibedakan mana yang berupa metode, teknik, dan struktur. Ketiga komponen ini seringkali tumpang tindih antarsatu sama lain. NHT juga dikenal sebagai metode, melainkan sebagai struktur dan teknik pembelajaran kooperatif.

Penerapan teknik pembelajaran kooperatif NHT merujuk pada konsep Kagan (1992) dalam Riyanto (2009: 273) dengan menggunakan struktur empat fase sebagai sintaks NHT, antara lain : Fase pertama : Numbering (Penomoran), guru membagi siswa ke dalam kelompok 4-5 orang, kepada setiap anggota 
kelompok diberi nomor 1-5 (sesuai jumlah anggota kelompok) dan masingmasing kelmpok memiliki nama yang berbeda. Fase kedua : Questioning (Mengajukan Pertanyaan), guru mengajukan sebuah pertanyaan kepada siswa. Pertanyaan dapat bervariasi. Pertanyaan dapat amat spesifik ataupun secara umum. Fase ketiga : Heads Together (berfikir bersama), siswa menyatukan pendapatnya terhadap jawaban pertanyaan itu dan meyakinkan tiap anggota dalam timnya mengetahui jawaban tim. Fase keempat : Answering (Menjawab), guru memanggil suatu nomor tertentu, kemudian siswa yang nomornya sesuai mengacungkan tangannya dan mencoba menjawab pertanyaan. Pada akhir fase guru dan siswa bersama-sam menyimpulkan jawaban yang telah dikemukakan dari masing-masing nomor.

Ibrahim (2000) mengemukakan tiga tujuan yang hendak dicapai dalam pembelajaran kooperatif dengan teknik $N H T$ yaitu : Hasil belajar akademik struktural bertujuan untuk meningkatkan kinerja siswa dalam tugas-tugas akademik. Pengakuan adanya keragaman bertujuan agar ssiwa dapat menerima teman-temanya yang mempunyai berbagai latar belakang. Pengembangan keterampilan social bertujuan untuk mengembangkan keterampilan sosial siswa

Keterampilan yang dimaksud antara lain berbagai tugas, aktif bertanya, menghargai pendapat orang lain, mau menjelaskan ide atau pendapat, bekerja dalam kelompok dan sebagainya.

Secara umum teknik pembelajaran Numbered Heads Together sangat bermanfaat, karena dapat berimplikasi positif untuk pembelajaran yang dikelola dalam kelas. Diantaranya ialah (1) Meningkatkan kepercayaan diri yang tinggi bagi pendidik maupun peserta didik, (2) Membuat anak didik bersemangat mengikuti pembelajran sehingga masuk kelas tepat waktu, (3) Membangun hubungan positif antar siswa melalaui diskusi dan kerjasama, (4) Perilaku anak ddik lebih teratur dalam mengikuti pelajaran, (5) Meminimalisir konflik atau permasalahan, (6) Siswa semakin memahami materi, (7) Menumbuhkan sikap saling menghargai, (8) Meningkatkan hasil belajar anak didik.

Setiap metode, struktur dan teknik pembelajaran tentu memiliki kelebihan dan kekurangan Kelebihan NHT yaitu : 1) Masing - masing dari peserta didik akan menjadi lebih siap untuk proses pembelajaran 2) Pembelajaran yang dilaksanakan dengan diskusi dapat menumbuhkan sikap sosial atau kerja sama yang positif 3) Peserta didik yang pandai dapat mengajari yang kurang pandai atau tutor sebaya. 4) Menarik minat belajar peserta didik 5) Memupuk rasa tanggung jawab yang tinggi pada diri setiap siswa untuk menyelesaikan tugas. Kekurangan NHT antara lain : 1) Adanya kemungkinan nomor yang sudah dipanggil dapat dipanggil kembali oleh guru. 2) Dimungkinkan nomor yang sama dari masing-masing anggota kelompok tidak memiliki kesempatan untuk presentasi mewakili kelompoknya.

\section{METODE}

Penelitian ini dilakukan di SDN Kepanjenkidul 2 Kecamatan Kepanjenkidul Kota Blitar. Waktu penelitian dimulai dengan permohonan izin kepada kepala sekolah yaitu pada tanggal 20 Maret 2017 dilanjutkan dengan pelaksanaan penelitian siklus I pertemuan ke-1 pada Hari Rabu, tanggal 29 April 2017 dan pertemuan ke-2 pada Hari Jum'at tanggal 31 Maret 2017. Siklus II

296 BRILIANT: Jurnal Riset dan Konseptual Volume 2 Nomor 3, Agustus 2017 
pertemuan ke-1 dilaksanakan pada Hari Senin, 3 April 2017 dan pertemuan ke-2 pada Hari Jum'at, 7 April 2017.

Subjek penelitian ini adalah guru kelas III sebagai peneliti dan siswa kelas III SDN Kepanjenkidul 2 Kota Blitar. Siswa kelas III berjumlah 24 siswa dengan jumlah siswa perempuan 9 anak dan jumlah siswa laki-laki.15 anak.

Penelitian ini menggunakan pendekatan penelitian korelasional yaitu penelitian yang dilakukan pada saat peneliti mengkaji hubungan antar variabel dengan menganalisis arah dan besaran hubungan antar variabel serta tingkat signifikansi hubungan antar variable (Adriani, 2010) Dalam hal ini variabel yang dimaksud adalah Guru berusaha melihat pengaruh penerapan suatu metode, model, strategi ataupun teknik pembelajaran tertentu terhadap penguasaan murid untuk mata pelajaran tertentu.

Jenis penelitian ini adalah Penelitian Tindakan Kelas (PTK). Menurut John Elliot (Sukarsono, 2012), bahwa yang dimaksud PTK ialah kajian tentang situasi social dengan maksud untuk meningkatkan kualitas tindakan di dalamnya. Wardhani (2010) menjelaskan Penelitian Tindakan Kelas adalah penelitian yang dilakukan oleh guru di dalam kelasnya sendiri melalui refleksi diri, dengan tujuan untuk memperbaiki kinerjanya sebagai guru, sehingga hasil belajar siswa menjadi meningkat.

Bentuk yang diambil dalam penelitian ini adalah Penelitian Tindakan Guru sebagai Peneliti. Kasbolah (Sudikin, 2010) menerangkan bahwa bentuk penelitian tindakan kelas yang memandang guru sebagai peneliti memiliki ciri penting, yaitu sangat berperannya guru itu sendiri dalam proses penelitian tindakan kelas. Dalam bentuk ini, tujuan utama penelitian tindakan kelas adalah untuk meningkatkan praktik-praktik pembelajaran di kelas. Dalam kegiatan tersebut guru bertindak langsung secara penuh dalam proses perencanaan, tindakan, observasi dan refleksi. Dalam hal ini peranan guru sangat dominan sehingga apabila ada keterlibatan pihak lain dari luar hanya bersifat konsultatif.

Model penelitian yang digunakan dalam penelitian ini adalah model dari Kemmis dan Mc. Taggart. Dalam perencanaannnya Kemmis menggunakan system spiral refleksi diri yang dimulai dengan rencana, pelaksanaan, pengamatan, refleksi, dan perencanan kembali yang merupakan dasar untuk suatu ancang-ancang pemecahan permasalahan.

Peneliti membagi tahap tindakan dalam penelitian ini menjadi dua siklus. Setiap siklus terdiri dari dua pertemuan. Setiap pertemuan diterapkan teknik pembelajaran kooperatif NHT.

Adapun penjabaran dari pelaksanaan tindakan Siklus I dan Siklus II sebagai berikut : Tahap perencanaan kegiatan yang dilakukan peneliti adalah menyusun RPP, melakukan pengaturan dan penyusunan jadwal kegiatan, menyiapkan media, penetapan target keberhasilan pembelajaran dan membuat instrument pengamatan untuk merekam kejadian selama proses pembelajaran.

Pelaksanaan tindakan penelitian ini dilaksanakan dalam dua siklus, masing-masing siklus terdiri dari dua pertemuan. Dalam satu pertemuan membutuhkan waktu 2 x 35 menit. Di SDN Kepatenjenkidul 2 Kota Blitar telah menggunakan Kurikulum 2013 sejak tahun 2013. Sehingga dari kelas satu sampai dengan kelas enam telah menggunakan Kurikulum 2013. Jadwal pelaksanaan penelitian ini juga menyesuaikan dengan jadwal tematik yang diterapkan di sekolah.

297 BRILIANT: Jurnal Riset dan Konseptual Volume 2 Nomor 3, Agustus 2017 
Dalam proses pengumpulan data, peneliti melakukan pengamatan dan mencatat semua hal yang terjadi selama pelaksanaan tindakan untuk memperoleh data yang akurat untuk perbaikan siklus selanjutnya. Kegiatan pengamatan atau observasi dilaksanakan secara kolaboratif untuk mengamati keterampilan guru, serta hasil belajar siswa menggunakan pembelajaran kooperatir teknik NHT.

Setelah melakukan tindakan dan pengamatan pada setiap siklus, peneliti melakukan refleksi atas proses dan hasil pembelajaran yang telah tercapai. Peneliti melakukan koreksi terhadap apa yang sudah dilakukan, apa yang belum dilakukan, apa saja yang sudah dicapai, masalah apa saja yang belum terpecahkan, dan tindakan apa yang harus dilakukan untuk meningkatkan pemahaman siswa yang akan diimplementasikan pada siklus kedua.

Instrumen yang digunakan pada penelitian ini berfungsi sebagai alat pengumpul data keterlaksanaan pembelajaran dengan teknik pembelajaran kooperatir NHT. (1) Lembar observasi pelaksanaan teknik pembelajaran kooperatif NHT untuk guru dan siswa. Lembar ini disusun berdasarkan komponen dasar teknik pembelajaran kooperatif NHT. Pelaksanaannya sesuai pendapat Suharsimi Arikunto (2006:156) observasi atau yang disebut juga dengan pengamatan, meliputi kegiatan pemuatan perhatian terhadap suatu objek dengan menggunakan seluruh alat indera. Pengamatan merupakan teknik pengumpulan data, dimana peneliti melakukan pengamatan secara langsung ke objek penelitian untuk melihat kegiatan yang dilakukan. (2) Angket tertutup yang digunakan untuk mengetahui tanggapan siswa terhadap teknik pembelajaran kooperatif NHT. Angket ini dibagikan kepada siswa untuk mengetahui tanggapan siswa secara umum mengenai pelaksanaan pembelajaran di kelas. Kuesioner tertutup berisi pernyataan dan siswa tinggal membubuhkan tanda centang pada kolom "ya" atau "tidak". Sejalan dengan pendapat Arikunto (2006 : 152) yang mengatakan bahwa angket tertutup adalah angket yang sudah disediakann jawabannya sehingga responden diminta untuk memilih satu jawaban yang sesuai dengan karakteristik dirinya dengan cara melingkari atau checklist (3) Tes yang digunakan untuk mengukur pemahaman siswa tiap sisklus. Tes ini terdiri dari Tes Kerja kelompok dan Tes Kerja individu (tes individu). Lembar kerja ini berfungsi untuk mengefektifkan proses pembelajaran dan memberikan permasalahan maupun pertanyaan sesuai batasan-batasan materi yang dipelajari. Tes individu diberikan setiap akhir pertemuan dan pada akhir siklus diambil rata-rata nilai dua pertemuan. (4) Lembar catatan lapangan, untuk mencatat temuan-temuan dalam pelaksanaan pembelajaran.

Analisis data dilaksanakan sesudah data observasi, data tes, data angket terkumpul pada setiap akhir pertemuan. Analisis data yang dilakukan dalam penelitian ini adalah analisis data kualitatif dan data kuantitatif. Adapun teknik analisis data diuraikan sebagai berikut: Data observasi aktivitas guru diperoleh melalui kegiatan observasi yang dilakukan oleh observer. Hasil observasi aktivitas guru akan digunakan untuk mengukur keterlaksanaan pembelajaran melalui Tehnik pembelajaran kooperatif NHT. Hasil observasi dianalisis dengan menggunakan rumus sebagai berikut:

Persentase Nilai $=\frac{\text { Jumlah skor yang diperoleh }}{\text { Jumlah skor maksimal }} \times 100 \%$

298 BRILIANT: Jurnal Riset dan Konseptual

Volume 2 Nomor 3, Agustus 2017 
Kriteria keberhasilan observasi aktivitas guru dikatakan berhasil apabila prosentase nilai observasi aktivitas guru sekurang-kurangnya dalam kategori baik.

Data observasi aktivitas siswa diperoleh melalui kegiatan observasi yang dilakukan oleh observer. Hasil observasi aktivitas siswa digunakan untuk mengukur keterlaksanaan pembelajaran melalui tehnik pembelajaran kooperatif NHT. Hasil observasi dianalisis dengan menggunakan rumus sebagai berikut:

$$
\text { Persentase Nilai }=\frac{\text { Jumlah skor yang diperoleh }}{\text { Jumlah skor maksimal }} \times 100 \%
$$

Selanjutnya kesimpulan hasil analisis data disesuaikan dengan kriteria keberhasilan hasil observasi. Kualitas pembentukan kompetensi dapat dilihat dari segi proses dan dari segi hasil. Dari segi proses pembentukan kompetensi dapat dikatakan berhasil dan berkualitas apabila keseluruhan atau setidak-tidaknya sebagian besar (75\%) siswa terlibat secara aktif (Mulyasa, 2010; 256).

Kriteria keberhasilan hasil observasi siswa dikatakan baik jika hasil persentase pencapaian nilai observasi aktivitas siswa secara klasikal sekurang-kurangnya $75 \%$.

Data Angket digunakan untuk memperoleh data tentang respon siswa terhadap keterlaksanaan pembelajaran melalui teknik pembelajaran kooperatif NHT. Lembar angket diberikan setiap akhir tindakan pertemuan 1 dan 2 pada siklus 1 dan 2 Setelah data angket terkumpul dilakuan analisis data angket dengan menggunakan rumus : $A K=\frac{s}{m x n} \times 100 \%$

Keterangan :

$A K=$ Prosentase pencapaian secara klasikal

$s \quad=$ Jumlah perolehan skor secara klasikal

$m=$ Skor maksimum angket

$n$ = Banyaknya siswa pengisi angket

Kualitas pembentukan kompetensi dapat dilihat dari segi proses dan dari segi hasil. Dari segi proses pembentukan kompetensi dapat dikatakan berhasil dan berkualitas apabila keseluruhan atau setidak-tidaknya sebagian bersar $(75 \%)$ siswa terlibat secara aktif (Mulyasa, 2010; 256).

Kriteria hasil angket dikatakan mendapat respon baik dari siswa jika hasil prosentasi pencapaian secara klasikal sekurang-kurangnya $75 \%$.

Pada penelitian ini untuk memperoleh data hasil belajar siswa diberikan test akhir yang di lakukan setiap akhir pertemuan. Test akhir merupakan test tulis. Setiap soal diberi skor sesuai dengan pedoman penskoran, Adapun nilai test diperhitungkan menurut rumus: $N A=\frac{\text { Nilai perolehan }}{\text { Nilai Max }} \times 100$

Hasil Nilai Akhir dalam kriteria baik apabila hasil nilai akhir siswa mencapai ketuntasan klasikal atau sekurang-kurangnya $85 \%$ dari jumlah siswa dalam kelas mencapai KKM. Kriteria Ketuntasan Minimal (KKM) materi bangun ruang sisi datar adalah 75. Menurut Trianto, (2009:241) yaitu suatu kelas dikatakan tuntas belajarnya (ketuntasan klasikal) jika dalam kelas tersebut terdapat $\geq 85 \%$ siswa yang telah tuntas belajarnya. 


\section{HASIL}

Data yang diuraikan pada tahap ini adalah data yang diperoleh dari tahap tindakan siklus I pertemuan pertama dan pertemuan kedua, refleksi siklus I dan data yang diperoleh dari tahap tindakan siklus II pertemuan pertama, pertemuan kedua, refleksi siklus II.

\section{Siklus I}

\section{Pertemuan ke-1}

Pada tahap perencanaan, guru kelas III membuat RPP. tentang Bumi Bagian dari Alam Semesta dengan menerapkan teknik pembelajaran kooperatif NHT. sesuai dengan kurikulum 2013, menyusun dan mempersiapkan lembar observasi untuk guru mengenai proses pengelolaan pembelajaran berdasarkan penerapan teknik pembelajaran kooperatif NHT, lembar observasi siswa, lembar tes individu dan kelompok, dan angket.

Pelaksanaan tindakan dilakukan berdasarkan rencana pelaksanaan pembelajaran yang sudah disusun pada tahap perencanaan. Siklus I pertemuan ke1 dilaksanakan pada hari Rabu, 29 Maret 2017. Kegiatan pendahuluan diawali dengan salam pembuka, doa yang dipimpin salah satu siswa. Guru melakukan apersepsi dengan memberikan pertanyaan berkaitan dengan bumi, bulan dan matahari. Selanjutnya guru menginformasikan materi yang akan dipelajari serta tujuan pembelajaran. Guru memanggil siswa untuk menjadi model matahari, bulan dan bumi.

Kegiatan inti diawali fase numbering, dengan membagi kelas menjadi 6 kelompok. Masing-masing kelompok terdiri dari 4 siswa. Kelompok tersebut diberi nama kelompok Merkurius, Venus, Bumi, Mars, Yupiter dan Saturnus . Guru memberi nomor dengan meminta siswa menyebutkan angka satu sampai dengan nomor 4 secara bergantian.

Fase kedua questioning, guru memberikan pertanyaan kepada siswa dengan cara memanggil perwakilan kelompok untuk maju mengambil gulungan kertas berisi soal. Siswa dipersilakan kembali ke tempat duduk. Soal tersebut kemudian dibacakan depan kelas untuk didiskusikan bersama kelompok. Sebelum membacakan pertanyaan siswa dalam kelas harus sepakat bahwa tidak boleh ada yang menjawab tanpa dipanggil nomornya terlebih dahulu. Jika ada salah satu anggota kelompok yang menjawab sebelum dipanggil maka akan mengurangi point kelompok tersebut.

Pada fase ketiga Heads Together, siswa membacakan pertanyaan yang diambil oleh salah satu siswa dalam gulungan kertas kecil. Kemudian Siswa menyatukan pendapatnya terhadap jawaban pertanyaan itu dan meyakinkan tiap anggota dalam timnya mengetahui jawaban tim

Pada fase keempat Answering, guru memanggil nomor tertentu, kemudian siswa yang nomornya sesuai mengacungkan tangannya dan mencoba menjawab pertanyaan. Jawaban siswa tersebut merupakan gambaran dari jawaban kelompoknya. Guru kemudian membagikan tes individu dan meminta siswa untuk mengerjakan tes tersebut.

Penilaian aktivitas guru menggunakan lembar observasi guru yang diisi oleh observer yaitu guru kelas dua. Aspek yang diamati dalam lembar observasi guru dengan menerapkan teknik pembelajaran kooperatif NHT ada tigabelas 
aspek. Dari tigabelas aspek tersebut lima aspek belum muncul dan delapan aspek telah muncul.

Penilaian observer dalam lembar observasi aktivitas siswa terdapat tiga aspek. Ketiga aspek tersebut merupakan respon dari aktivitas yang dilaksanakan guru dalam proses pembelajaran mulai dari kegiatan awal, kegiatan inti dan kegiatan akhir. Terdapat 11 anak telah dapat menjawab pertanyaan ketika dipanggil nomornya, 17 anak telah aktif berdiskusi dengan kelompoknya, dan 16 anak dapat memberikan pendapat saat presentasi, dengan persentase $61,11 \%$ termasuk kategori kurang.

Perolehan hasil kerja kelompok pada siklus I pertemuan ke-1. Kelompok Merkurius mendapat nilai 70, Venus mendapat nilai 95, Mars mendapat Nilai 75, Bumi mendapat nilai 80, Yupiter mendapat nilai 90, dan Saturnus mendapat nilai 75. Kemenangan Kelompok dimenangkan oleh Kelompok Venus.

Hasil tes individu siswa kelas III pada siklus I pertemuan ke-1 sebesar 1700. Nilai rata-rata hasil belajar siswa adalah 70,83. Siswa yang tuntas sebanyak 14 anak sehingga persentase ketuntasan belajar klasikal sebesar 58,33\%. Termasuk kategori kurang.

Selama pelaksanaan tindakan pada siklus I pertemuan ke-1 observer menemukan beberapa hal antara lain : guru telah menerapkan teknik pembelajaran kooperatif NHT, guru juga telah menggunakan media yang sesuai dengan materi pelajaran, namun guru belum membagi siswa dengan lebih heterogern dalam hal kemampuan akademis. Guru juga telah menentukan nomor siswa dalam setiap kelompoknya yaitu dengan meminta siswa untuk menyebutkan secara urut nomor 1 sampai dengan 4 dalam setiap kelompok. Siswa yang menyebut nomor 1 berarti siswa tersebut memiliki nomor 1 . Penomoran tersebut memang sudah baik namun jika tidak ada nomor secara nyata yang bisa dipegang atau digunakan siswa kadang masih rancu menyebut dirinya nomor berapa. Untuk itu diharapkan pada pertemuan berikutnya guru telah menyiapkan nomor untuk tiap siswa dalam kelompok.

Hasil angket yang diberikan kepada siswa setelah pelaksanaan pembelajaran adalah sebagai berikut : 1) pada aspek pertama, sebanyak 19 siswa menjawab iya dan 5 anak menjawab tidak. 2) pada aspek kedua, sebanyak 4 siswa menjawab iya dan 20 siswa menjawat tidak 3) pada aspek ketiga, sebanyak 11 siswa menjawab iya dan 13 siswa menjawab tidak 4) pada aspek keempat, sebanyak 10 siswa menjawab iya dan 14 siswa menjawab tidak 5) pada aspek kelima, sebanyak 8 siswa menjawab iya dan 16 siswa menjawab tidak. Rekapitulasinya dapat kita lihat dalam tabel di bawah ini :

\section{Pertemuan ke-2}

Pada tahap perencanaan, guru kelas III membuat RPP tentang proses Terjadinya Siang dan Malam dengan menerapkan teknik pembelajaran kooperatif NHT. sesuai dengan kurikulum 2013, menyusun dan mempersiapkan lembar observasi untuk guru dan siswa mengenai proses pengelolaan pembelajaran berdasarkan penerapan teknik pembelajaran kooperatif NHT, lembar tes individu dan kelompok, serta angket.

Pelaksanaan tindakan dilakukan berdasarkan rencana pelaksanaan pembelajaran yang sudah disusun pada tahap perencanaan. Siklus I pertemuan ke2 dilaksanakan pada hari Jum'at, 31 Maret 2017. Kegiatan pendahuluan diawali

301 BRILIANT: Jurnal Riset dan Konseptual Volume 2 Nomor 3, Agustus 2017 
dengan salam pembuka, doa yang dipimpin salah satu siswa. Guru melakukan apersepsi dengan memberikan pertanyaan berkaitan dengan gerak rotasi dan gerak revolusi. Selanjutnya guru menginformasikan materi yang akan dipelajari serta tujuan pembelajaran yaitu mempelajari proses terjadinya siang dan malam. Guru meminta salah satu siswa mendemostrasikan proses siang dan malam menggunakan globe dan senter. Guru menugaskan salah satu siswa untuk membaca teks siang dan malam

Kegiatan inti diawali fase numbering, dengan membagi kelas tetap menjadi 6 kelompok. Masing-masing kelompok terdiri dari 4 siswa. Guru membagikan topi bernomor kepada masing-masing kelompok. Setiap kelompok mendapat topi dengan nomor 1 sampai dengan 4.

Fase kedua questioning, gmeminta siswa untuk berpendapat bagaimana jika seandainya terjadi siang terus atau malam terus sepanjang masa? Sebelum berpendapat siswa diperbolehkan berdiskusi terlebih dahulu. Guru kemudian membagikan soal untuk dikerjakan secara berkelompok (LKK).

Pada fase ketiga Heads Together, siswa bersama kelompoknya berdiskusi untuk menyelesaikan tugas kelompoknya.

Pada fase keempat Answering, guru memanggil nomor tertentu, kemudian siswa yang nomornya sesuai mengacungkan tangannya dan mencoba menjawab pertanyaan. Guru juga memberi kesempatan kepada kelompok untuk mempresentasikan bersama kelompoknya di depan kelas, dengan catatan jika peserta dari kelompok lain bermaksud menanggapi atau mengajukan pertanyaan kepada kelompok tersebut, maka boleh menunjuk siswa dengan nomor kepala tertentu untuk menjawab pertanyaannya. Guru kemudian membagikan tes individu dan meminta siswa untuk mengerjakan tes tersebut.

Dari tigabelas aspek dalam lembar observasi guru siklus I pertemuan ke2 terdapat sepuluh aspek yang sudah muncul dan tiga aspek belum muncul. Aspek yang belum muncul yaitu guru bersama murid menyimpulkan materi dan memberikan evaluasi, memberikan penghargaan kepada kelompok yang berhasil menjawab semua pertanyaan dan memilki kekompakan dan melakukan refleksi pembelajaran.

Penilaian observer dalam lembar observasi aktivitas siswa terdapat tiga aspek. Ketiga aspek tersebut merupakan respon dari aktivitas yang dilaksanakan guru dalam proses pembelajaran mulai dari kegiatan awal, kegiatan inti dan kegiatan akhir. Terdapat 15 anak telah dapat menjawab pertanyaan ketika dipanggil nomornya, 19 telah aktif berdiskusi dengan kelompoknya, dan 16 anak dapat memberikan pendapat saat presentasi.

Perolehan hasil kerja kelompok pada siklus I pertemuan ke-2adalah sebagai berikut : kelompok Merkurius mendapat nilai 80, Venus mendapat nilai 90, Mars mendapat nilai 80, Bumi mendapat nilai 85, Yupiter mendapat nilai 90, dan Saturnus mendapat nilai 80. Kemenangan Kelompok dimenangkan oleh Kelompok Venus dan Yupiter.

Jumlah hasil belajar siswa kelas III pada siklus I pertemuan ke-2 sebesar 1880. Nilai rata-rata hasil belajar siswa adalah 78,33 termasuk dalam kriteria cukup baik. Siswa yang tuntas sebanyak 19 anak sehingga persentase ketuntasan belajar klasikal sebesar 79,17\%. Dengan presentase tersebut maka tingkat keberhasilan dalam kategori cukup baik.

302 BRILIANT: Jurnal Riset dan Konseptual Volume 2 Nomor 3, Agustus 2017 
Catatan Lapangan selama pelaksanaan tindakan pada siklus I pertemuan ke-2 menunjukkan guru telah menerapkan teknik pembelajaran kooperatif NHT, guru juga telah menggunakan media yang sesuai dengan materi pelajaran, guru juga telah membagi siswa dengan lebih heterogern dalam hal kemampuan akademis. Guru juga telah membagikan nomor kepala untuk memudahkan siswa mengingat nomor berapakah dirinya. Penataan tempat duduk juga telah baik, semua siswa tidak ada yang membelakangi papan tulis.

Hasil angket yang diberikan kepada siswa setelah pelaksanaan pembelajaran adalah sebagai berikut : 1) pada aspek pertama, sebanyak 21 siswa menjawab iya dan 3 anak menjawab tidak. 2) pada aspek kedua, sebanyak 11 siswa menjawab iya dan 13 siswa menjawat tidak 3) pada aspek ketiga, sebanyak 16 siswa menjawab iya dan 8 siswa menjawab tidak 4) pada aspek keempat, sebanyak 17 siswa menjawab iya dan 7 siswa menjawab tidak 5) pada aspek kelima, sebanyak 19 siswa menjawab iya dan 6 siswa menjawab tidak.

Berdasarkan tindakan dan hasil observasi pada siklus I, dapat diketahui bahwa pada pertemuan 1 dan 2 aktivitas guru dan siswa mengalami peningkatan. Selain itu hasil belajar siswa juga mengalami peningkatan baik hasil kerja kelompok maupun hasil kerja individu. Hingga silus I pertemuan ke-2 guru belum memberikan penghargaan kepada kelompok pemenang.

\section{Siklus II}

\section{Pertemuan ke-1}

Pada tahap perencanaan, guru kelas III membuat RPP dengan menerapkan teknik pembelajaran kooperatif NHT sesuai dengan kurikulum 2013, menyusun dan mempersiapkan lembar observasi untuk guru mengenai proses pengelolaan pembelajaran berdasarkan penerapan teknik pembelajaran kooperatif NHT, lembar observasi siswa, lembar tes individu dan kelompok serta angket angket.

Pelaksanaan tindakan dilakukan berdasarkan rencana pelaksanaan pembelajaran yang sudah disusun pada tahap perencanaan. Siklus II pertemuan ke-1 dilaksanakan pada hari Senin, 3 April 2017. Kegiatan pendahuluan diawali dengan salam pembuka, doa yang dipimpin salah satu siswa. Guru melakukan apersepsi dengan memberikan pertanyaan berkaitan dengan kelebihan bumi jika dibandingkan dengan planet lain. Selanjutnya guru menginformasikan materi yang akan dipelajari serta tujuan pembelajaran.

Kegiatan inti diawali fase numbering, dengan membagi kelas menjadi 6 kelompok dan diberi nama kelompok Merkurius, Venus, Bumi, Mars, Yupiter dan Saturnus. Guru membagi nomor kepala kepada setiap siswa.

Fase kedua questioning, Guru mendemonstrasikan Globe. Globe merupakan tiruan bumi. Warna biru pada globe menunjukkan perairan. Warna biru pada globe lebih luas dari pada warna yang lain.berarti perairan lebih luas daripada daratan. Guru memanggil salah satu nomor siswa untuk membaca teks informative pada buku siswa tentang keutamaan bumi. Guru memberi kesempatan kepada siswa untuk bertanya tentang materi dalam teks informatif yang belum dimengerti. Kemudian guru membagikan lembar kerja kelompok

Pada fase ketiga Heads Together, siswa bersama kelompoknya menyatukan pendapat bekerjasama untuk menyelesaikan soal-soal pada lembar kerja kelompok.

303 BRILIANT: Jurnal Riset dan Konseptual Volume 2 Nomor 3, Agustus 2017 
Pada fase keempat Answering, guru memanggil suatu nomor tertentu, kemudian siswa yang nomornya sesuai mengacungkan tangannya dan mempresentasikan jawaban dari kelompoknya.

Aktivitas guru telah memunculkan 11 aspek dari 13 aspek yang ada. Persentase keberhasilan termasuk dalam kategori baik yaitu mencapi $84 \%$.

Penilaian observer dalam lembar observasi aktivitas siswa terdapat tiga aspek. Ketiga aspek tersebut merupakan respon dari aktivitas yang dilaksanakan guru dalam proses pembelajaran mulai dari kegiatan awal, kegiatan inti dan kegiatan akhir. Terdapat 16 anak telah dapat menjawab pertanyaan ketika dipanggil nomornya, 20 anak telah aktif berdiskusi dengan kelompoknya, dan 18 anak dapat memberikan pendapat saat presentasi.

Perolehan hasil kerja kelompok pada siklus II pertemuan ke-1. Kelompok Merkurius mendapat nilai 80, Venus mendapat nilai 95, Mars mendapat Nilai 80, Bumi mendapat nilai 90, Yupiter mendapat nilai 100, dan Saturnus mendapat nilai 75. Kemenangan Kelompok dimenangkan oleh Kelompok Yupiter.

Jumlah hasil belajar siswa kelas III pada siklus II pertemuan ke-1 sebesar 1920. Nilai rata-rata hasil belajar siswa adalah 70,83 termasuk dalam kriteria baik. Siswa yang tuntas sebanyak 14 anak sehingga persentase ketuntasan belajar klasikal sebesar $83,33 \%$.

Catatan Lapangan selama pelaksanaan tindakan pada siklus II pertemuan ke-1 observer menemukan beberapa hal antara lain : guru telah melaksanakan pembelajaran sesuai RPP, guru juga telah memberikan penghargaan kepada kelompok dengan perolehan nilai tertinggi. Hadiah yang diberikan meski sederhana diharapkan bisa memotivasi siswa lain untuk berpartisipasi aktif dalam kegiatan kelompok. Penghargaan yang diberikan kepada siswa berupa makanan snack sebenarnya kurang tepat, apalagi snack tersebut bukanlah termasuk dalam kategori makanan sehat. Untuk pertemuan berikutnya diharapkan hadiah yang diberikan berupa alat tulis atau apapun yang sifatnya mendidik.

Hasil angket yang diberikan kepada siswa setelah pelaksanaan pembelajaran siklus II pertemuan ke-1 adalah sebagai berikut : 1) pada aspek pertama, sebanyak 21 siswa menjawab iya dan 3 anak menjawab tidak. 2) pada aspek kedua, sebanyak 18 siswa menjawab iya dan 6 siswa menjawat tidak 3) pada aspek ketiga, sebanyak 20 siswa menjawab iya dan 4 siswa menjawab tidak 4) pada aspek keempat, sebanyak 17 siswa menjawab iya dan 7 siswa menjawab tidak 5) pada aspek kelima, sebanyak 21 siswa menjawab iya dan 3 siswa menjawab tidak.

\section{Pertemuan ke-2}

Pada tahap perencanaan guru kelas III sebagai peneliti membuat RPP. tentang bagian-bagian bumi dengan menerapkan teknik pembelajaran kooperatif NHT sesuai dengan kurikulum 2013, menyusun dan mempersiapkan lembar observasi untuk guru dan siswa mengenai proses pengelolaan pembelajaran berdasarkan penerapan teknik pembelajaran kooperatif NHT, lembar tes individu dan kelompok, serta angket.

Pelaksanaan tindakan dilakukan berdasarkan rencana pelaksanaan pembelajaran yang sudah disusun pada tahap perencanaan. Siklus II pertemuan ke-2 dilaksanakan pada hari Jum'at, 7 April 2017. Kegiatan pendahuluan diawali dengan salam pembuka, doa yang dipimpin salah satu siswa. Guru melakukan

304 BRILIANT: Jurnal Riset dan Konseptual Volume 2 Nomor 3, Agustus 2017 
apersepsi dengan memberikan pertanyaan berkaitan dengan bagian-bagian bumi. Selanjutnya guru menginformasikan materi yang akan dipelajari serta tujuan pembelajaran yaitu mempelajari bagian-bagian bumi.

Kegiatan inti diawali fase numbering, guru membagi nomor kepala untuk dipakai oleh siswa. Guru memasang poster bagian-bagian bumi. Guru memanggil salah satu nomor siswa dan menugaskan untuk membaca nyaring teks informative berjudul bagian-bagian bumi

Fase kedua questioning, guru menugaskan siswa untuk mengeluarkan telur rebus yang dibawa dari rumah. Guru menugaskan untuk membelah telur tersebut dengan pisau kemudian membandingkan bagian-bagian bumi dengan bagian telur tersebut. Guru membagikan soal untuk dikerjakan secara berkelompok (LKK).

Pada fase ketiga Heads Together, siswa bersama kelompoknya berdiskusi untuk menyelesaikan tugas kelompoknya.

Pada fase keempat Answering, Guru memberi kesempatan kepada kelompok yang sudah selesai terlebih dahulu untuk mempresentasikn hasil kelompoknya. Anggota kelompok tersebut wajib menjawab pertanyaan dari anggota kelompok lain yang sesuai dengan nomor kepalanya. Atau secara acak sesuai permintaan kelompok penanya. Pada akhir kegiatan kelompok guru mengumumkan kelompok pemenang pada hari itu dan mendapatkan hadiah atau penghargaan dari guru.

Guru kemudian membagikan lembar kerja individu untuk dikerjakan secara individu. Tahap selanjutnya guru membahas tes individu dan mengakhir pembelajaran dengan doa dan salam

Dari tigabelas aspek dalam lembar observasi guru siklus II pertemuan ke2 semua aspek telah muncul sehingga persentasenya mencapai $100 \%$, dengan kategori keberhasilan sangat baik.

Penilaian observer dalam lembar observasi aktivitas siswa terdapat tiga aspek. Ketiga aspek tersebut merupakan respon dari aktivitas yang dilaksanakan guru dalam proses pembelajaran mulai dari kegiatan awal, kegiatan inti dan kegiatan akhir. Terdapat 14 anak telah dapat menjawab pertanyaan ketika dipanggil nomornya, 24 anak telah aktif berdiskusi dengan kelompoknya, dan 12 anak dapat memberikan pendapat saat presentasi.

Perolehan hasil kerja kelompok pada siklus II pertemuan ke-2. Kelompok Merkurius mendapat nilai 90, Venus mendapat nilai 100, Mars mendapat nilai 90, Bumi mendapat nilai 95, Yupiter mendapat nilai 95, dan Saturnus mendapat nilai 90. Kemenangan Kelompok dimenangkan oleh Kelompok Venus

Jumlah hasil belajar siswa kelas III pada siklus II pertemuan ke-2 sebesar 1980. Nilai rata-rata hasil belajar siswa adalah 82,5 termasuk dalam kriteria baik. Siswa yang tuntas sebanyak 21 anak sehingga persentase ketuntasan belajar klasikal sebesar $87,5 \%$. Dengan presentase tersebut maka tingkat keberhasilan dalam kategori baik.

Catatan Lapangan selama pelaksanaan tindakan pada siklus II pertemuan ke-2, guru telah menerapkan teknik pembelajaran kooperatif NHT, guru telah membagi siswa dengan lebih heterogern dalam hal kemampuan akademis. Guru juga telah membagikan nomor kepala untuk dipakai setiap siswa untuk menarik minat belajar siswa dan memudahkan siswa mengingat nomor dirinya. Guru juga telah mengeksplorasi pemahaman siswa dengan melakukan percobaan sederhana.

305 BRILIANT: Jurnal Riset dan Konseptual Volume 2 Nomor 3, Agustus 2017 
Pada tahap akhir guru telah memberikan hadiah yang lebih baik yaitu sebuah penggaris busur kepada anggota kelompok yang memperoleh nilai tertinggi.

Hasil angket yang diberikan kepada siswa setelah pelaksanaan pembelajaran adalah sebagai berikut : 1) pada aspek pertama, sebanyak 21 siswa menjawab iya dan 3 anak menjawab tidak. 2) pada aspek kedua, sebanyak 18 siswa menjawab iya dan 6 siswa menjawat tidak 3) pada aspek ketiga, sebanyak 20 siswa menjawab iya dan 4 siswa menjawab tidak 4) pada aspek keempat, sebanyak 17 siswa menjawab iya dan 7 siswa menjawab tidak 5) pada aspek kelima, sebanyak 21 siswa menjawab iya dan 3 siswa menjawab tidak.

Berdasarkan tindakan dan hasil observasi pada siklus II, dapat diketahui bahwa pada pertemuan 1 dan 2 aktivitas guru dan siswa mengalami peningkatan. Siswa lebih bersemangat mengikuti kegiatan kelompok. Peningkatan siswa juga meningkat dengan ditandai meningkatnya hasil belajar siswa pada ranah kognitif. Guru telah dapat mengelola kelas dengan baik. Guru juga telah memberikan penghargaan kepada kelompok pemenang.

\section{PEMBAHASAN}

\section{Keterlaksanaan Teknik Pembelajaran Kooperatif NHT}

Keterlaksanaan teknik pembelajaran kooperatif NHT dalam penelitian ini ditunjukkan dengan (1) hasil observasi aktivitas guru dalam melaksanakan pembelajaran sesuai langkah-langkah NHT (2) hasil observasi aktivitas siswa dalam mengikuti pembelajaran dan (3) hasil angket siswa setelah dilaksanakan pembelajaran dengan teknik pembelajaran kooperatif NHT. Dari siklus 1 dan siklus 2 diperoleh hasil observasi aktivitas guru pada siklus 1 pertemuan ke-1 mendapatkan persentase $62 \%$ dalam kriteria kurang, pertemuan ke-2 mendapatkan persentase $76 \%$ dalam kriteria cukup baik, sehingga terjadi kenaikan $14 \%$ dan pada siklus 2 pertemuan ke-1 mendapatkan persentase $84 \%$ dalam kriteria baik dan pertemuan ke-2 mendapatkan persentase $100 \%$ dalam kriteria sangat baik, ada kenaikan $16 \%$. Jika digambarkan dalam bentuk diagam batang adalah sebagai berikut :

\section{Diagaram 1 Hasil Observasi Aktivitas Guru}

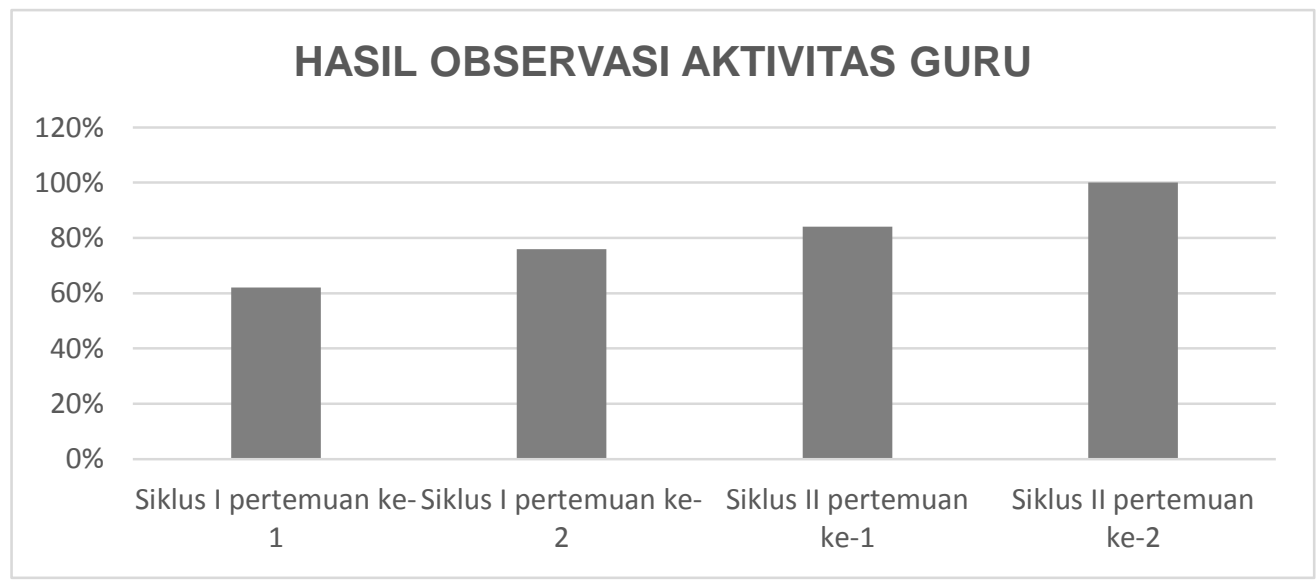

Sedangkan hasil observasi aktivitas siswa pada siklus 1 pertemuan ke-1 mendapatkan presentase $61,1 \%$ dalam kriteria kurang, pertemuan ke-2 
mendapatkan persentase 69,44\% dalam kriteria kurang, ada kenaikan 8,34\% dan siklus 2 pertemuan ke-1 mendapatkan persentase $75 \%$ dalam kriteria baik dan pertemuan ke-2 mendapatkan persentase $84,72 \%$ dalam kriteria baik terdapat kenaikan $9,72 \%$. Diagram batang data tersebut adalah sebagai berikut :

\section{Diagram 2 Hasil Observasi Aktivitas Siswa}

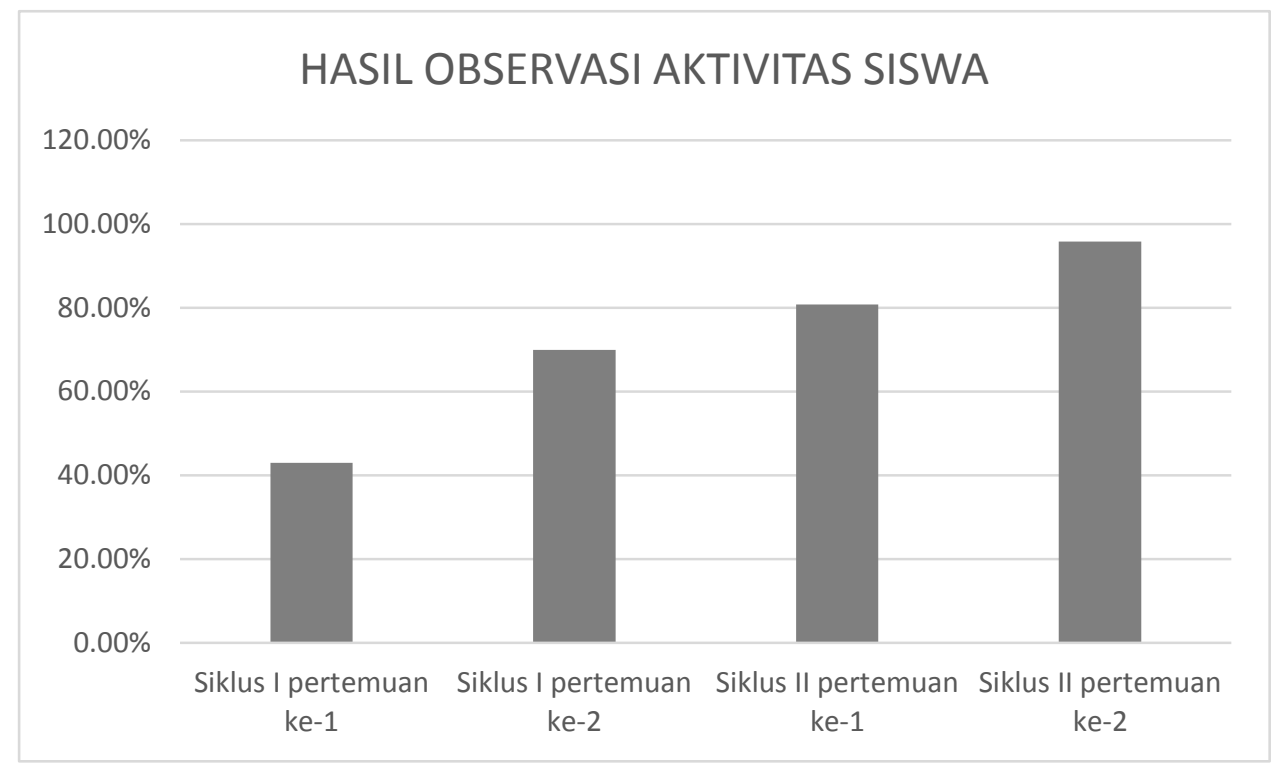

Hasil angket siswa pada siklus 1 pertemuan ke-1 mendapatkan presentase $43 \%$ dalam kriteria belum mendapat respon positif, pertemuan ke-2 mendapatkan persentase $70 \%$ dalam kriteria mendapat respon positif, dan siklus 2 pertemuan ke- 1 mendapatkan persentase $80,8 \%$ dalam kriteria mendapat respon positif, dan pertemuan ke-2 mendapatkan persentase 95,8\% dalam kriteria mendapat respon positif. Peningkatannya dapat kita lihat pada diagram berikut ini:

\section{Diagram 3 Hasil Angket Siswa}

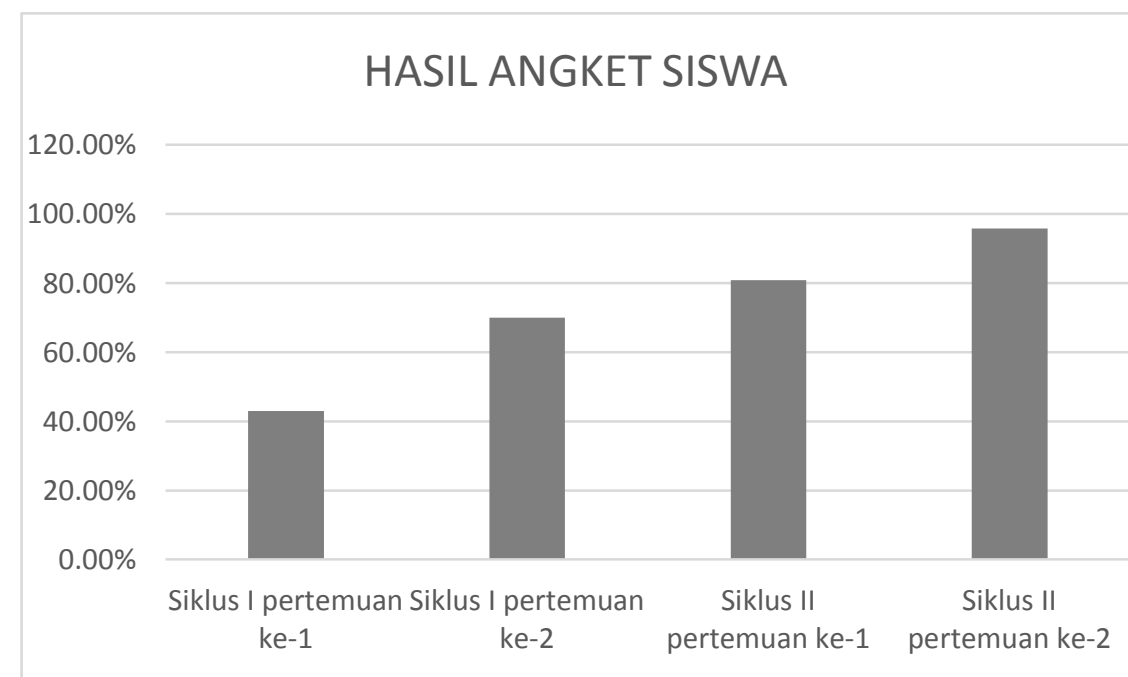

307 BRILIANT: Jurnal Riset dan Konseptual

Volume 2 Nomor 3, Agustus 2017 
Berkaitan dengan ini, Sudjana (2009: 65) menyatakan bahwa penilaian proses belajar mengajar yang dapat mengungkapkan keterlaksanaan kegiatan belajar-mengajar baik oleh guru maupun siswa adalah melalui observasi. Melalui observasi didapatkan keaslian data primer yang diperoleh dari pelaku yang diobservasi. Dan menurut teori behavioristik, belajar adalah perubahan tingkah laku sebagai akibat dari adanya interaksi antara stimulus dan respon. Seseorang dianggap telah belajar sesuatu apabila ia mampu menunjukkan perubahan tingkah laku. Dengan kata lain, belajar merupakan bentuk perubahan yang dialami siswa dalam hal kemampuannya untuk bertingkah laku dengan cara yang baru sebagai hasil interaksi antara stimulus dan respon.Keterlaksanaan pembelajaran dalam penelitian ini ditunjukkan oleh hasil observasi aktivitas guru sebagai data wajib dan hasil observasi aktivitas siswa sebagai data pendukung serta dilengkapi dengan hasil respon siswa sebagai data peuunjang. Aktivitas siswa dalam pelaksanaan pembelajaran merupakan bentuk respon yang ditunjukkan siswa, dari hasil stimulus yang diberikan guru pada saat melaksanakan pembelajaran.

Data keterlaksanaan pelaksanaan pembelajaran yang dihasilkan dalam penelitian ini selalu menunjukkan kenaikan hasil dan kriteria yang konsisten mulai dari pertemuan ke-1, pertemuan ke-2 siklus 1 dan pertemuan 1, pertemuan ke-2 siklus 2. Berdasarkan indikator keberhasilan yang sudah ditetapkan di bab III dapat diambil kesimpulan bahwa penerapan teknik pembelajaran kooperatirf NHT pada materi bumi bagian dari alam semesta terbukti efektif.

\section{Pemahaman Siswa Pada Materi Bumi Bagian dari Alam Semesta}

Pemahaman siswa dalam penelitian ini ditunjukkan oleh (1) hasil nilai kerja kelompok (2) hasil nilai tes individu. Adapun hasil nilai kerja kelompok siklus I pertemuan ke-1 mendapatkan presentase $80,83 \%$ dalam kriteria baik, pertemuan ke-2 mendapatkan persentase $84,16 \%$ dalam kriteria baik, sudah menunjukkan kenaikan hasil persentase 3,33\%, Sedangkan siklus 2 pertemuan ke1 mendapatkan persentase $88,33 \%$ dalam kriteria baik dan pertemuan ke-2 mendapatkan persentase 93,33\% dalam kriteria sangat baik, menunjukkan kenaikan persentase hasil belajar siswa sebesar 5\%. Data peningkatan tersebut dapat disajikan dalam diagram berikut ini :

Diagram 4 Hasil Nilai Kerja Kelompok

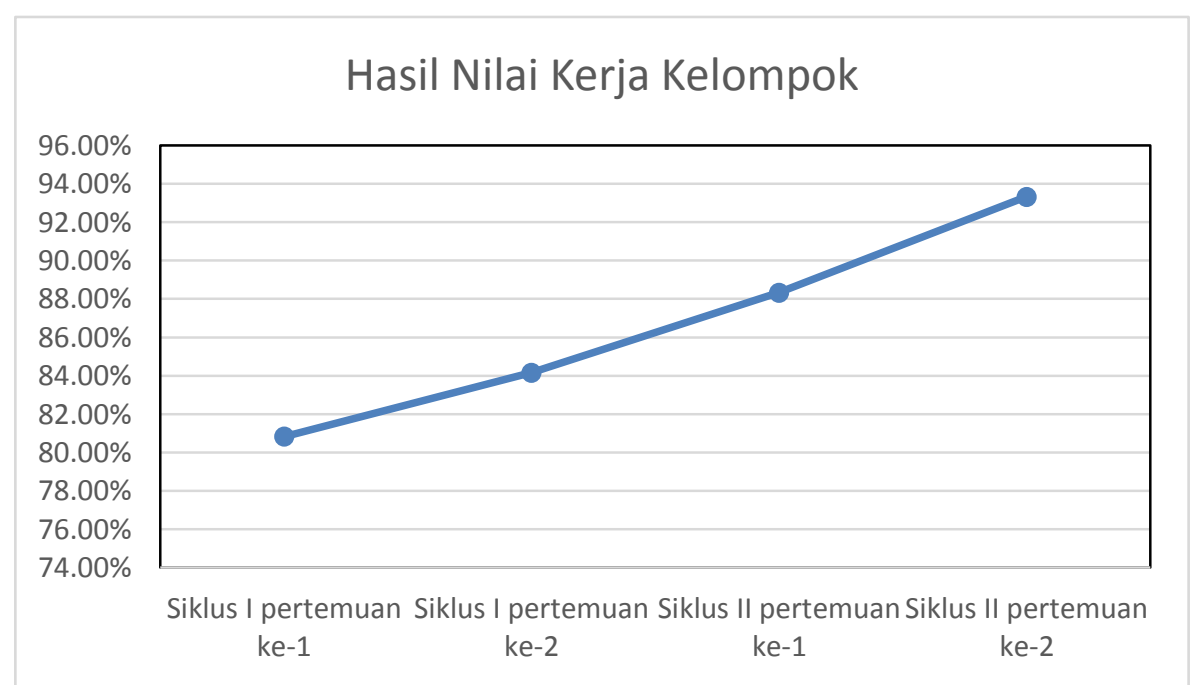


Kenaikan persentase Kegiatan Kerja Kelompok pada setiap pertemuan dalam siklus I dan siklus II menununjukkan adanya kerja sama yang baik di dalam kelompok. Hal ini sesuai dengan pendapat Lie (1999) dalam Hamsa (2009), mengemukakan bahwa pembelajaran kooperatif tipe Numbered Head Together (NHT) mendorong siswa untuk meningkatkan kerja sama mereka.

Adapun hasil nilai Tes individu siklus I pertemuan ke-1 mendapatkan presentase $58,33 \%$ dalam kriteria dalam kriteria belum mencapai ketuntasan klasikal, pertemuan ke-2 mendapatkan persentase 79,17\% dalam kriteria belum mencapai ketuntasan klasikal, meskipun demikian sudah menunjukkan kenaikan hasil persentase $20.84 \%$, Sedangkan siklus 2 pertemuan ke-1 mendapatkan persentase $83,33 \%$ dalam kriteria sudah mencapai ketuntasan klasikal dan pertemuan ke-2 mendapatkan persentase $87,5 \%$ dalam sudah mencapai ketuntasan klasikal dengan kenaikan sebesar 4,17\%. Data tersebut dapat digambarkan dalam diagram berikut ini.

\section{Diagram 5 Hasil Tes Individu}

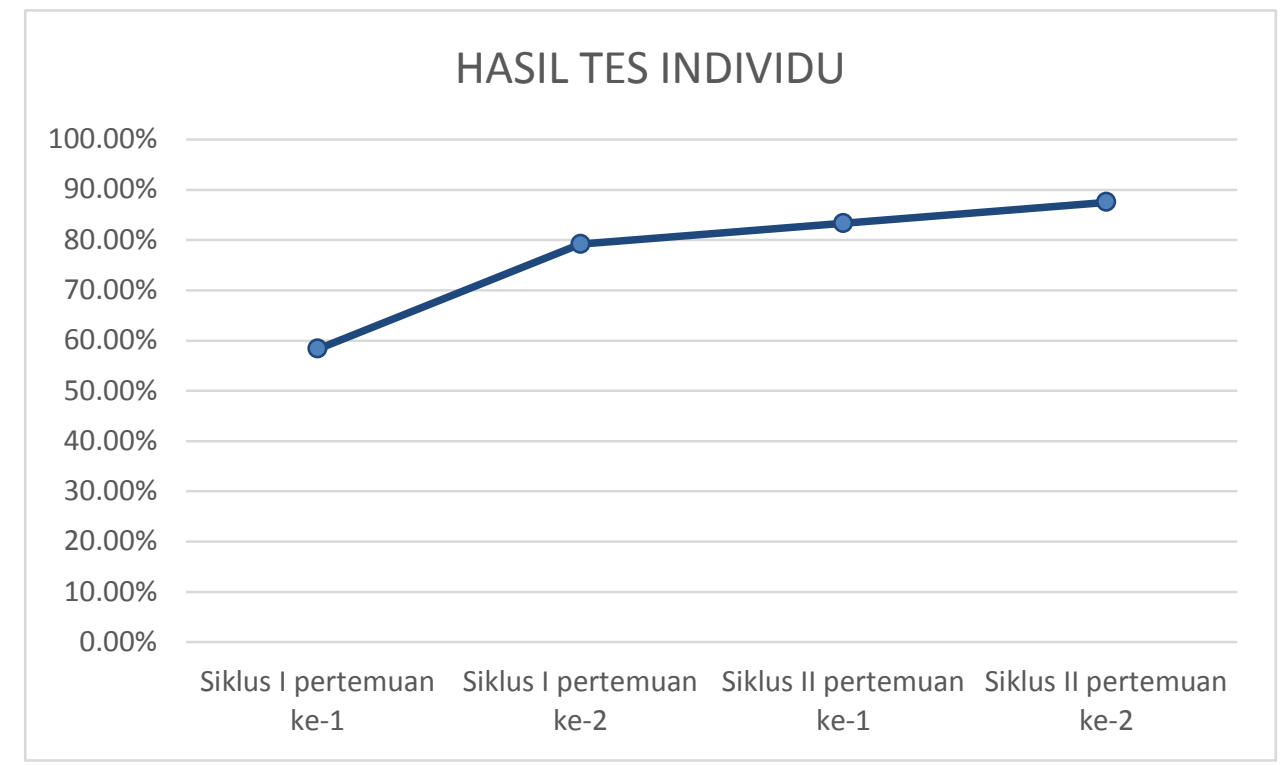

Kenaikan tersebut menunjukkan bukti bahwa NHT dapat membantu siswa mencapai ketuntasan belajar klasikal, yang berarti adanya peningkatan dalam hal pemahaman siswa. Hal tersebut sejalan dengan pendapat Spenser Kagen pada tahun 1993 dalam Trianto (2009) yang menyebutkan bahwa NHT dapat melibatkan lebih banyak siswa dalam menelaah materi yang tercakup dalam suatu pelajaran dan mengecek pemahaman mereka terhadap isi pelajaran.

Hasil belajar siswa pada materi bumi bagian dari alam semesta setelah dilaksanakan model pembelajaran kooperatif teknik NHT telah teruji dan terbukti menunjukkan pemahaman siswa yang semakin meningkat dengan meningkatnya hasil belajar siswa secara konsisten. Berdasarkan hasil penelitian menunjukkan model pembelajaran kooperatif teknik NHT pada materi bumi bagian dari alam semesta dilaksanakan melalui proses membangun pemahaman untuk membuat pembelajaran menjadi bermakna. Pada saat proses membangun pemahaman 
siswa dalam pembelajaran ini melalui langkah-langkah NHT membutuhkan untuk menyatukan kepala bersama atau bekerja antara individu dalam kelompok.

Berdasarkan pembahasan ini sesuai dengan indikator keberhasilan yang sudah ditetapkan dapat diambil kesimpulan bahwa teknik pembelajaran kooperatif NHT dapat meningkatkan pemahaman tentang bumi bagian dari alam semesta bagi siswa kelas III SDN Kepanjenkidul Kota Blitar.

Pelaksanaan teknik pembelajaran kooperatif NHT dalam penelitian ini tidak terlepas dari berbagai kendala. Kendala yang muncul dalam penelitian ini dapat dibagi dalam tiga aspek, yaitu aspek guru, aspek siswa, dan aspek lembar kerja. Kendala yang terjadi dari aspek guru, guru belum dapat menggunakan waktu sesuai dengan yang direncanakan dalam RPP. Hal ini terjadi pada kegiatan awal, ketika pangaturan duduk kelompok. Untuk itu, guru berupaya mengatur penggunaan waktu secara efektif dan efisien, dengan menyampaikan pada siswa untuk duduk berdekatan dengan anggota kelompok pada pertemuan sebelumnya. Sementara itu, kendala yang terjadi dari aspek siswa antara lain siswa, masih ada siswa yang tergantung pada guru. Oleh karena itu, selama pembelajaran guru harus selalu memberikan motivasi, bimbingan, perhatian, dan penguatan kepada siswa. Hal ini bertujuan agar siswa lebih aktif dan antusias dalam mengerjakan tugasnya, sehingga siswa tidak bergantung pada guru dalam belajar. Sedangkan, kendala yang ada dari aspek lembar kerja, terdapat beberapa kalimat yang sulit dipahami maksudnya. Untuk mengatasi hal ini, guru memberikan bimbingan dengan menggunakan bahasa yang komunikatif supaya bisa dipahami siswa.

\section{KESIMPULAN}

Berdasarkan pembahasan pada bab IV maka hasil penelitian dapat disimpulkan: (1) Penerapan Teknik Pembelajaran Kooperatif NHT pada siswa kelas III SDN Kepanjenkidul 2 tentang Bumi Bagian dari Alam Semesta teruji efektif. Terbukti dari data keterlaksanaan pelaksanaan pembelajaran yang dihasilkan dalam penelitian ini selalu menunjukkan hasil kenaikan persentase dan kriteria yang selalu konsisten dari pertemuan ke-1, pertemuan ke-2 siklus I dan pertemuan ke-1, pertemuan ke-2 siklus II. (2) Terjadi peningkatan pemahaman siswa setelah dilaksanakan Teknik Pembelajaran Kooperatif NHT dengan meningkatnya hasil belajar siswa dari siklus I pertemuan ke-1, pertemuan ke-2 dan siklus II pertemuan ke-1 dan pertemuan ke-2 penelitian ini. Berdasarkan hasil (1) dan (2) dapat ditarik simpulan bahwa Penerapan Teknik Pembelajaran Kooperatif NHT dapat Meningkatkan Pemahaman tentang Bumi Bagian dari Alam Semesta Siswa Kelas III SDN Kepanjenkidul 2.

\section{SARAN}

Bagi guru, diharapkan guru dapat mempersiapkan segala sesuatunya lebih matang sehingga penggunaan waktu saat pelaksanaan pembelajaran lebih efektif dan efisien, sesuai dengan yang direncanakan dalam RPP. Bagi siswa, diharapkan siswa mempunyai kreativitas sendiri dan tidak selalu bergantung pada guru, siswa lebih bisa menghargai waktu dan selalu membiasakan diri untuk membaca. Bagi peneliti lain, diharapkan dapat mengembangkan penerapan teknik pembelajaran kooperatif NHT di kelas yang berbeda atau pada kompetensi dasar yang berbeda. Bagi Sekolah, diharapkan sekolah bisa membuat kebijakan mengenai penyediaan buku-buku di perpustakaan sebagai bahan referensi untuk

310 BRILIANT: Jurnal Riset dan Konseptual Volume 2 Nomor 3, Agustus 2017 
penelitiian guru-guru dan bahan bacaan siswa. Sekolah juga diharapkan membuat kebijakan mengenai penyediaan sarana prasarana pembelajaran yang memadai.

\section{DAFTAR PUSTAKA}

Arikunto, Suharsimi. (2006). Prosedur Penelitian Suatu Pendekatan Praktek. Jakarta : Rineka Cipta.

Huda, Miftahul. 2013. Cooperatif Learning Metode, Teknik, Struktur dan Model Penerapan, Yogjakarta : Pustaka Pelajar

Ibrahim, M. 2000. Pembelajaran Kooperatif, Surabaya: Universitas Negeri Surabaya

Mulyasa, E. 2010. Penelitian Tindakan Sekolah. Bandung: Remaja Rosda Karya.

Permendikbud Nomor 81 A Tahun 2013 lampiran IV. Kementerian Pendidikan dan Kebudayaa. (Online), (https://luk.staff.ugm.ac.id/atur/bsnp/ permendikbud81A 2013Implementasi K13Lengkap.pdf), diakses tanggal 23 Maret 2017.

Riyanto, Y. 2009. Paradigma Pembelajaran. Jakarta: Kencana.

Sudjana, Nana. 2009. Penilaian Hasil dan Proses Belajar Mengajar.Bandung: Remaja Rosdakarya

Sukidin, Basrowi, dan Suranto. 2010. Manajemen Penelitian Tindakan Kelas. Surabaya: Insan Cendekia.

Sumiati, A. 2009. Metode Pembelajaran. Bandung: Wacana Prima.

Wardhani, I. G. A. K. Wihardit. 2010. Penelitian Tindakan Kelas. Jakarta: Universitas Terbuka. 